\title{
PIONEER
}

VOLUME 13, Issue 1, June 2021: 105-121

\section{STRENGTHS AND WEAKNESSES OF COLLABORATIVE WRITING AND PEER FEEDBACK IN AN EFL INTENSIVE READING AND WRITING COURSEWORK}

\author{
Sakhi Herwiana \\ Universitas Hasyim Asy'ari Tebuireng Jombang \\ herwianas@yahoo.com
}

\begin{abstract}
*Corresponding author, email: herwianas@yahoo.com
Received : April 23, $2021 \quad$ Revised : June 16, 2021

Accepted : June 19, $2021 \quad$ Published : June 30, 2021
\end{abstract}

\begin{abstract}
The advantages of collaborative writing and peer feedback have contributed to give significant effect to the writing ability of L1 (first language) learners, L2 (second language) learners, and FL (foreign language) learners. The objective of this study was to find out the strengths and weaknesses of collaborative writing and peer feedback in an EFL intensive reading and writing coursework classroom especially in English education department students of Hasyim Asy'ari University. This study used a qualitative method where the data were described qualitatively. As this study used a qualitative approach, therefore observation and interview were used as instruments to collect the data. The result showed that collaborative writing and peer feedback strategies were not easy to be implemented in an EFL classroom. There were some strengths and weaknesses found during the observation. The strengths of these strategies showed that students could share ideas, improve grammar and vocabulary, make students more active, have good cooperation among peers, build self-confidence and make students happy. However, the strategies may not give any significant effect on the students' cognitive ability in writing skills if most of the students have the low ability in mastering English. In addition, a smart student would prefer to write individually than in collaborative writing.
\end{abstract}

Keywords: collaborative writing, EFL classroom, peer feedback

\section{INTRODUCTION}

Mastering English is important for students as English would give many beneficial points for their future career world. In mastering English, there should be four skills to be understood, those are reading, writing, listening, and speaking. Writing and reading are part language skills that have to be mastered in acquiring English and could be first taught for the students as they considered into passive English skills. However, there are some challenges faced by Indonesian educators in teaching writing and reading to EFL students. Most Indonesian students have difficulties when writing in English 
because they do not master complex grammatical structures, and they do not know how to write the content (Ariyanti, 2016). In addition, some external factors may influence the success of writing such as the teachers often teach in a big class, and the time allotment is limited to explain the material (Ariyanti, 2016). Meanwhile, in reading class, there are some problems students have. Difficulty factors faced by the students are divided into external and internal factors. Internal factors include physics, intellectual, and psychological, while external factors include family and school environments (Hidayati, 2018a). Some internal factors influence the students ' reading comprehension that is generally found by the reader during reading, namely; difficulty in understanding long sentences and text, the difficulty that is caused by limited background knowledge, difficulty in using reading strategies, and difficulty in concentration (Hidayati, 2018b).

Meanwhile, teaching writing to English department students of Hasyim Asy'ari University is a challenge, especially in intensive reading and writing coursework. When students are asked to write, they do not know how to start. They also lack ideas. It is because they do not like to read. Reading habit is very poor in Indonesia. They do not have any motivation to read books, articles, magazines, or newspapers, especially in English literature. They do not have any ideas to write. Students are only able to write essays or paragraphs about their life experiences. Nevertheless, it is very difficult for them to construct writing. These problems become attention in writing class. Furthermore, the course is only two credits (100 minutes). There is not enough time to teach, give explanation, and review the students' writing products one by one because the class consisted of 28 students and the English lecturer did not have any assistant who help her.

Therefore, one way to solve the problems in writing class is the use of a teaching strategy. Many previous studies proved that collaborative writing is effective to use in teaching writing. Some studies showed that collaborative writing brought positive attitudes among ESL learners (Veramuthu \& Shah, 2020). Based on their study, it can be assumed that collaborative writing is effective to facilitate students' learning. Moreover, collaborative writing could make the class more lively and make students comfortable in joining the writing class (Nelson, 2000). Another study showed that collaborative writing could stimulate students' ideas and activating their background knowledge of the topics assigned to develop writing (Anggraini, Rozimela, \& Anwar, 2020). Moreover, 
collaborative writing could make students enjoy the activities in writing (Murtiningsih, 2016).

Not only collaborative writing but peer feedback was also implemented in this study. Many studies proved that peer feedback gives a lot of benefits. A study in China found that collaborative writing can change students' attitudes in interaction, the quantity of language-related episodes (LREs), and the quality of engagement in solving the LREs. This study also found that English-learning beliefs and experiences, observed value of friends' support, and group relationships or dynamics were three major factors that shape students' attitudes through collaborative writing (Chen \& Yu, 2019). The study of peer review in EFL classrooms at Ecuador University could give advantages to students' critical thinking, collaborative work, and composition quality (Harutyunyan \& Poveda, 2011). Studies in Taiwan also stated that peer feedback was effective in learning English writing (Lin \& Chien, 2009). In addition, the result of peer feedback in Turki implied that peer feedback reduced students' anxiety in writing, improved confidence, and writing by collaboration and learning together (Yastıbaş \& Yastıbaş, 2015). Moreover, a study of collaborative writing showed that collaborative writing was more accurate than collaborative prewriting and no collaboration (McDonough, De Vleeschauwer, \& Crawford, 2018). There are a lot of previous studies showed the positive impacts of collaborative writing and peer feedback in ESL and EFL classrooms. According to the explanation above, therefore the implementation of collaborative writing and peer feedback was used in this study.

The difference and gaps between those previous studies and this study are in this current study, the students were given a text reading first at the beginning of the activities. We can see it as an upgraded strategies to teach collaborative writing to the students. While in those previous studies, the students were not given a text reading; they were not asked to read any text. Reading activities in this study are aimed to stimulate students' schemata to create ideas in writing.

The objective of the study in this research is to try to find out the strengths and weaknesses of collaborative writing and peer feedback in an EFL classroom especially in English education department students of Hasyim Asy'ari University. 


\section{REVIEW OF LITERATURE}

\section{Collaborative writing}

Collaborative writing is one of the strategies used to teach writing where students work together in groups or pairs (Sukirman, 2016). Students are asked to make a group then they are asked to write an essay with their friends in a group. They have to work together and share their ideas to produce one writing composition or essay.

According to Huett \& Koch (2011), some strategies in collaborative writing that can be adapted are as follows:

- One or two persons in a group have to take notes of the topic that is discussed together. The function of this stage is to make the draft, revise and compare each other ideas.

- Developing an outline together for the essay or composition that will be written.

- Writing a paper or an essay together. It can guarantee that students do not write only one person's idea or multiple ideas. Choose the best student to be the writer. Other students can give their ideas to the writer to write the sentences.

- Revising and editing together. This step decides whether the writing product is good or not. In this activity, the students in a group can change sentences, paragraphs, and ideas.

- Asking the students to read their writing product out loud. This activity is to make students discuss whether the sentence, paragraph, or ideas in their writing product connects each other.

\section{Peer Feedback}

Peer feedback is comments and revision given by students to their friends' writing products. Liu and Hansen ( 2002 cited in Yastıbaş \& Yastıbaş, 2015) stated that peer feedback is when students use sources of information and interaction with each other in such a way to take responsibility in commenting draft on each other in the process of writing. Peer review feedback has been used by the teachers in the first language and second language countries to teach writing (Lin \& Chien, 2009). The researchers who study peer feedback also found that peer feedback has a lot of benefits in learning writing. 


\section{Reading}

Reading was applied in this study as the first activity. The researcher applied reading because reading can give students background knowledge to create the story in their writing and can improve vocabulary (Herwiana, 2021). Vocabulary and writing have a strong correlation (Herwiana, 2021). Reading can automatically increase students' ability on writing and speaking because they acquire vocabulary through it (Nelson, Michal, \& Perfetti, 2005 cited in Duff, Tomblin \& Catss, 2015). Reading text can give prospects for improvement in vocabulary acquisition (Duff et al., 2015). The most common practice in a Reading classroom is reading and discussing a particular passage in detail. The students are to identify the main idea of the text, find the details about the text, understand the text structure, and scrutinize the meaning of the words in context as well as guess the unknown vocabulary, to find the referents, etc. This is in line with what (Hidayati, 2018a) ; (Ng, Renandya, \& Chong, 2019) define intensive reading as reading carefully. Teachers mostly focus on all the skills and strategies required to understand a text. They will give close guidance in discussing the text to ensure the students accurately comprehend the text. This approach directly helps learners to develop their reading skills and comprehension. Moreover, intensive reading is text reading or passage reading. In this reading, the learner reads the text to get knowledge or analysis. The goal of this reading is to read shorter text. Learners read the book to acquire knowledge is the kind of intensive reading. Intensive reading would provide a basis for explaining difficulties in the structure and of extending knowledge and vocabulary and idioms. It would also provide material for developing greater control of the language in speech and writing.

\section{METHOD}

\section{Research design}

This research used the qualitative research method. "...Qualitative research is done by analyzing the words than numbers and by reporting in-depth views of the people who have been studied... Qualitative research is a study which tries to find the what, how, when, and where of an event or an action to define its meaning, perceptions and definitions, characteristics, metaphors, codes, and explanations." (Angrosino in Latief, 2013). 
A qualitative study design was implemented as a way to analyze the students' perceptions and creating ideas that are used to increase the educational program (Hande, 2014). The researcher used observation and interviews on collecting the data. The interview was delivered twice. Firstly, the researcher used written open-ended questionaire to collect and record the data so that there would be no missing points. It was distributed to each student in that class. After that, the researcher conducted an informal interview with the students to follow up on the unclear answers to get more explanation and some clarification in the observation section so that the data could be drawn deeply.

The strategy was conducted in four meetings. The observations were done four times to give a more comprehensive depiction of the attitude and location of what was observed. Within the observation, each topic of reading was given level by level starting from the easiest level of reading to encourage students to conduct collaborative writing. In the first meeting, the intensive reading was given within easy level topic of reading so that the students know how to do the collaborative writing through intensive reading. The second till the fourth observation was done through the following plot. The implementation of the strategy was conducted when the students were attending the subject of intensive course 2 (reading and writing). Twenty-eight students were attending intensive course 2 in that class and all of them were asked to join the strategy. There was no need to ask permission to implement the strategy because the researcher taught this subject. In this study, the researcher as a lecturer who conducted collaborative writing and peer feedback in an intensive course 2 class, and she was helped by the other lecturer as an observer.

Collaborative writing and peer feedback were conducted into some steps. The first step was reading. The purpose of reading as the first step was aimed to give background knowledge to the students and learn new vocabulary. As the students' level of English was intermediate and beginner, therefore, the text was chosen based on the students' comprehension level of English so the topics and vocabulary were simple. There were four reading texts with different topics that were given to the students. The topics of the texts were lying, losing something, computer games, and fairy tale. In this step, the students had to read the text, answered the questions, studied difficult vocabulary, and discussed it with the lecturer in the class. 
After that, the students were asked to make groups that were chosen by the lecturer based on their academic ability. Each group consisted of four students. They were asked to write an argument or opinion or experience or a short story related to the topic of the text that had been read before. In this step, the students had to collaborate with their friends in the group, they shared their idea, wrote, discussed, edited, and revised their writing product.

The next step was peer feedback. After they finished writing then they were asked to give their writing product to other groups. They had to give a review of the others' writing products. They had to read carefully, and checked if there were any mistakes in grammar, punctuation, and spelling. After they finished giving review feedback, they had to give it back to their friends.

In the last step, the students' writing products were submitted to the lecturer. The lecturer gave a score and review the students' writing product.

\section{Participants}

There were 28 students which consisted of 5 Thai students and 23 Indonesian students who participated in this study. They were five male students and twenty-three female students. Their age is around 18- 20 years old. The participants were secondsemester students at the English Education Department of Hasyim Asy'ari University in Jombang, East Java. The Indonesian students were in the intermediate level proficiency of English, while the Thai students were at the beginner level. The students were attending intensive course 2 (writing and reading). In doing the strategy the students were divided into some groups. The groups were chosen based on the students' academic reports in mastering English. A group consisted of two students who have low ability and two students who have high ability in English. However, there was an exception for the groups which was consisted of Thai students. A group consisted of only one Thai student and three Indonesian students. The exception was made because Thai students were at the beginner level.

\section{Research Instruments}

As this study used a qualitative approach, observation and interview were used as instruments to collect the data. The observation was done in the class during the implementation of collaborative writing and peer feedback. While the interview was in 
the form of a paper of open-ended questions consisted of five questions. The questions include; "What is your opinion regarding the implementation of collaborative writing and peer feedback?", "What are your difficulties in doing this strategy?", "What is the advantages of this strategy?", "What is the weakness of this strategy?", "Do you think collaborative writing and peer feedback can improve your writing ability?". The second interview was delivered in the informal situation by phone or face to face to get more explanation if there were some unclear answers.

\section{Data Collection Procedure}

The observation was done during the implementation of collaborative writing and peer feedback in the class. All of the students' activities, behaviors, and writing tasks were observed by the researcher and put in the note. The interview was given to the students in the last meeting after the implementation of the strategy. The strategy was implemented in four meetings, so the interview was distributed in the fifth meeting. The interview was conducted twice, the first interview was in the form of paper, and the second interview was conducted by phone or face to face in the informal situation to followed up the unclear explanation from the students' answers.

\section{Data Analysis}

In analyzing the data from the observation, the researcher checked the note and described it qualitatively. The data from the interview were analyzed then they were described qualitatively. After that, the researcher analyzed and summed up the results and described them.

\section{FINDINGS AND DISCUSSION}

\section{Findings}

\section{Strengths}

Based on the findings, the strengths of collaborative writing and peer feedback in an EFL classroom are enriching ideas, improving grammar, improving vocabulary, students can be more active, engaging good cooperation, building confidence, and make happy. 


\section{a. Enriching Ideas}

Collaborative writing can make students work together and share ideas in their group. In learning writing, students said that when they were asked to write an essay, they did not know what kind of the main idea should they write, so in collaborative writing, they could share ideas and discussed it with their friends. The students stated in the interview as follows,

\section{Excerpt 1}

"We get many ideas through collaborative writing".

\section{Excerpt 2}

"I can get new views and ideas".

Most of the students agree that collaborative writing can give many ideas. Sharing ideas may give benefit and make cooperation so that they can build the main idea for their essay.

\section{b. Improving Grammar}

Not all students in a group have a good comprehension of grammatical knowledge. In collaborative writing, clever students would help their friends to fix grammar to get a better result in writing products. Students who did not have good grammar would automatically learn the correct structures when their friends fixed the grammatical mistakes as seen in the student comment below,

\section{Excerpt 3}

"This method is good for me. My friends give me feedback and correct my grammar. So it can increase my grammar and new vocabulary”.

In addition, in doing peer feedback, students had to give feedback to others' essays. By this strategy, students also learned more about grammar when they reviewed others' writing products.

\section{c. Improving Vocabulary}

In collaborative writing, students help each other. If students do not know the English vocabulary their friends will help them. Clever students can help their friends with vocabulary. If their friends did not know the meaning of the words in English, those clever students helped them by translating the words in English. There are some statements from the students; 


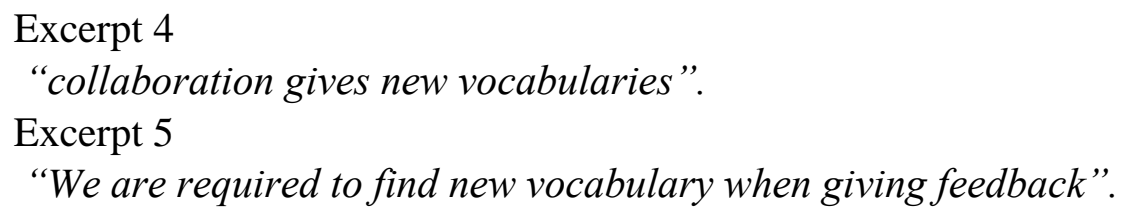

Moreover, in doing peer feedback students may get new vocabulary. Some students may not have many English vocabularies. They may learn it when giving reviews to their friends' essays.

\section{d. Students are More Active}

Less active students become more active while working together with their friends. Students had to give suggestions and opinions to reach one goal. By collaborative writing and peer feedback, students are forced to give ideas, comments, suggestions, and corrections to each other. The students' statements can be seen as follows,

Excerpt 6

" Through this strategy, I can directly show my arguments or opinions".

Excerpt 7

"We can have many good suggestions in cooperative learning".

\section{e. Engaging Good Cooperation}

Collaborative writing and peer feedback train students not to be an egoist. Students who have high ability in mastering English helped their friends who have the low ability in English. They helped each other in a group. They had to learn, write and discuss together to build a good writing product. So they could finish quickly. Student statement can be seen as follows;

\section{Excerpt 8}

"it can teach me not to be selfish, we can help each other when we don't know something and we can write the essay beautifully".

\section{f. Building confidence}

Students stated that peer feedback and collaborative writing could build their selfconfidence. It can be seen in the student statement as follows;

\section{Excerpt 9}

"It can make me confidence because my friends can correct my mistakes, we learn and we complement the weakness of the others". 
Students did not feel shy when working with their friends. They did not feel shy to ask questions, share ideas, and give suggestions to their friends than to the lecturer.

\section{g. Happy}

They felt relax and enjoy the writing process. Students felt happy working together with their friends than writing individually. It was because the students felt that the task was easier to do together than do it by one person. It can be seen in the following statements;

\section{Excerpt 10}

"This method gives fun and enjoy activities".

\section{Excerpt 11}

"These strategies can reduce nervous because my friends will help me".

\section{Excerpt 12}

"It can make us happy because we share the story too when we do the task".

Those statements show that the strategy give a positive impact on the students' psychological aspect. Collaborative writing and peer feedback can make students happy, reduce nervously, give fun, and enjoyable activities.

\section{Weaknesses}

However, beside having some strengths, the implementation of collaborative writing and peer feedback in an EFL classroom may have some weaknesses. There are some points regarding the weaknesses of the strategies which can be seen as follows;

\section{a. Misunderstanding}

Collaborative writing also brings misunderstanding among students in a group. Some students did not understand their friends' ideas. Students were difficult to combine one's idea and others. As seen from the students' statements below;

\section{Excerpt 13}

"my friends do not understand about my idea".

\section{Excerpt 14}

"it is difficult for me to set up the topic because there are many ideas and arguments".

\section{Excerpt 15}

"I have difficulties writing in the group when we have different ideas". 
In addition, based on the observation during the process of collaborative writing and peer feedback in the class, some students also did not understand the task given by the lecturer. It was because the students never have experience in conducting collaborative writing and peer feedback before.

\section{b. Cannot identify complex grammatical structures}

Students also have some complaints because they have difficulties in conducting this strategy, especially when giving peer feedback, especially in grammar. Students difficulties can be seen in the statements below;

Excerpt 16

"I don't know whether my review feedback is correct or not when I give the review to my friends' task".

\section{Excerpt 17}

"I just know a little grammar".

Students who did not master grammar well could not give a review of their friends' written tasks. They just got a little explanation about the mistakes from their friends. They did not know whether their feedback is right or wrong because some students had limited grammar knowledge.

\section{c. Individualism}

Some students could not give their opinion because one student wanted to do it by her/himself. Working with a different character to reach one goal is somewhat harder than working individually. Based on the interview, the smart student felt that he liked to write alone than doing collaborative writing. As he said in the statement below;

\section{Excerpt 18}

"I think this strategy is neither good nor bad, we actually can improve writing by reading English novels and practice it individually. I feel that I can write faster and better than writing collaboratively".

Only one student said that he liked writing individually. This student has a good academic report of English among others and has high self-confidence.

\section{d. Passive Students Do Not Contribute A Lot}

Through the observation in the class during the implementation of collaborative writing and peer feedback. It found that silent students would be less creative. Some 
students were passive and did not participate in doing the task. It can be seen in the students' statements as follows;

\section{Excerpt 19}

"I feel shy because I don't understand grammar. I am afraid and shy if my suggestion is wrong".

Shy students could not express their ideas/ opinions because they were afraid of making mistakes. This problem happened only for students who have low English mastery. These kinds of students did not have any ideas to share, no grammar knowledge, and lack of vocabulary. That was why they just kept silent while their friends working. It supported by other statements below;

\section{Excerpt 20}

"There are some of us who have the low ability in mastering English and they feel shy to express their opinion".

\section{Excerpt 21}

"When we are in collaborative writing, sometimes one of us or more do not have any suggestion. So she/he usually just keeps silent”.

\section{Excerpt 22}

"Sometimes it is difficult to do when there are only a few students who are active in discussion".

\section{Excerpt 23}

"It's so bad for the introvert student, especially for Thai students because we are shy and we can't do it and we just keep silent".

In this case, Thailand students were in the beginner level of English proficiency, and they were introverts therefore they just kept silent. In addition, students who have low English proficiency did not contribute a lot in doing the task.

\section{e. Students Cannot Write Freely}

Some students could not write all that they wanted because they had to share it with others. They could not write freely by themselves. The students' statements can be seen below;

\section{Excerpt 24 \\ "I cannot write freely with all of my ideas".}

Excerpt 25

"Sometimes I get difficulties to share my opinion because it will be skipped by my friends". 
They cannot practice writing with their idea because they have to work together in writing one essay. In collaborative writing, students had to reach one goal to write one writing product. So they felt that they could not write based on their ideas. This limitation made students respect others' ideas and eliminate their ideas.

\section{Discussion}

While many studies showed many advantages and satisfying results, this research showed that there were some difficulties in conducting the strategies. Implementing collaborative writing and peer feedback was not easy as it was thought, especially for EFL students whose English comprehension was not good enough. Even though there are some difficulties in conducting collaborative writing and peer feedback, there are many students said that collaborative writing is a good strategy to create a better writing product.

There are many strengths of collaborative writing. Students can have many ideas and new experiences by collecting their friends' ideas. It can help students to create ideas and content in their writing product (Anggraini, Rozimela \& Anwar, 2020). Collaborative writing and peer feedback also can improve students' vocabulary and grammar. It can be said that the strategy give a positive impact on students' cognitive ability in writing. It can help students in creating ideas to develop better writing, improving grammar and vocabulary (Hanifah, 2018).

Moreover, collaborative writing can build good teamwork. Students become more active in the process of learning writing than writing individually. They can help each other in a group. Students who have a high level of English mastery can help those who have difficulties in writing English. They worked together to write a good essay by engaging in good cooperation.

Another positive impact that can be seen in these strategies is that students are happy and enjoy the process of teaching and learning in writing class. They do not feel shy. They feel relax when doing the task because they work with their friends. It is supported with the research result that stated collaborative writing could build students' self-confidence in writing English (Anggraini, Rozimela \& Anwar, 2020), and peer feedback could decrease students' anxiety and growth students' confidence in writing (Yastıbaş \& Yastıbaş, 2015). 
Besides the strengths mentioned above, there are some weaknesses in conducting collaborative writing and peer feedback. When they share ideas in a group, their friends do not understand her/his ideas. Every student in a group has different ideas and opinions so it is difficult to combine the ideas. The past research study also faced the same problem, students were debating, trapped, and mixed up what they wanted to write in developing ideas (Hanifah, 2018).

The lack of grammar is the source of students' difficulty in doing peer feedback. They cannot give a maximum review of their friends' essays because of limited grammar knowledge (Hanifah, 2018). Peer feedback cannot give a significant impact on the students writing skills. They still need feedback from the lecturer.

Instead of working together, there is individualism in collaborative writing. A smarter student is better to write alone instead of writing together with their friends. Some students in a group feel that they do not have a high level of English mastery so they depend on the task of smart students. Students with a low level of English mastery will count the task on smart students (Hanifah, 2018).

Collaborative writing and peer feedback do not give a lot of advantages to passive students. These strategies are not suitable for students who have a low level of English proficiency. These strategies will run well for those who have a high level of English proficiency. Collaborative writing and peer feedback will have different results with different participants. However, past research that stated collaborative writing showed to have a significant effect on EFL students writing skills (Anggraini, Rozimela, \& Anwar, 2020) is not completely true.

Collaborative writing forces students to have one topic to write one writing product. This limitation eliminates students' ideas. They have to write with their friends' agreement and suggestions of the idea. So they cannot write based on one's idea.

\section{CONCLUSIONS AND SUGGESTIONS}

\section{Conclusions}

It can be concluded that the implementation of collaborative writing and peer feedback in an EFL classroom have strengths and weaknesses. Even though there are some weaknesses, these strategies have many advantages. Many students give positive feedback to the implementation of collaborative writing and peer feedback. While some students give negative feedback to these strategies. These strategies can collect students' 
ideas by sharing, improve grammar and vocabulary, make students more active, have good cooperation among peers, build self-confidence and make students happy.

\section{Suggestions}

These strategies are suggested to reduce boredom and get different experiences in writing class. In addition, the implementation of collaborative writing and peer feedback should be guided by the lecturer considering that EFL students do not have high ability in mastering English especially complex grammatical structures. These strategies may not give any significant effect on the students' cognitive ability in writing skills if most of the students have a low level of English proficiency.

\section{REFERENCES}

Anggraini, Rezy; Rozimela, Yenni; Anwar, D. (2020). The Effects of Collaborative Writing Activity on EFL Learners' Writing Skills and Their Perception of the Strategy. Journal of Language Teaching and Research, 11(2), 335-341. https://doi.org/http://dx.doi.org/10.17507/jltr.1102.25

Ariyanti. (2016). The Teaching of EFL Writing in Indonesia. Dinamika Ilmu, 16(2), 263. https://doi.org/10.21093/di.v16i2.274

Chen, W., \& Yu, S. (2019). A longitudinal case study of changes in students' attitudes, participation, and learning in collaborative writing. System, 82, 83-96. https://doi.org/10.1016/j.system.2019.03.005

Duff, D., Tomblin, J. B., \& Catss, H. (2015). The Influence of Reading on Vocabulary Growth: A Case for a Matthew Effect. Journal of Speech, Language, and Hearing Research, 58(3), 853-864. https://doi.org/10.1044/2015

Hande, S. (2014). Strengths weaknesses opportunities and threats of blended learning: Students' perceptions. Annals of Medical and Health Sciences Research, 4(3), 336. https://doi.org/10.4103/2141-9248.133455

Hanifah, Z. (2018). Strengths and Weaknesses to Teach EFL Students and Its Relation to Students 'Self-esteem in Writing. In 2 nd English Language and Literature International Conference (ELLiC) (Vol. 2, pp. 59-64).

Harutyunyan, L., \& Poveda, M. F. (2011). Students' Perception of Peer Review in an EFL Classroom. English Language Teaching, 11(4), 138. https://doi.org/10.5539/elt.v11n4p138

Herwiana, S. (2021). Strategy to Teach Writing in a Big Class. Jombang, Jawa Timur: LPPM UNHASY Tebuireng Jombang. 
Hidayati, D. (2018a). Extensive and intensive reading in an EAP setting. English for Specific Purposes, 16(1), 47-60. https://doi.org/10.1016/S0889-4906(96)00031-2

Hidayati, D. (2018b). Students Difficulties in Reading Comprehension At. Students Difficulties in Reading Comprehension At.

Huett, A., \& Koch, R. T. (2011). COLLABORATIVE WRITING STRATEGIES.

Latief, M. A. (2013). Research Methods on Language Learning an Introduction (2nd Ed.). Malang: UM Press.

Lin, G. H. C., \& Chien, P. S. C. (2009). An Investigation into Effectiveness of Peer Feedback. Journal of Applied Foreign Languages Fortune Institute of Technology, 3(1983), 79-87.

McDonough, K., De Vleeschauwer, J., \& Crawford, W. (2018). Comparing the quality of collaborative writing, collaborative prewriting, and individual texts in a Thai EFL context. System, 74, 109-120. https://doi.org/10.1016/j.system.2018.02.010

Murtiningsih, S. (2016). Collaborative Writing in an EFL Context. Journal of Foreign Language Teaching and Learning, 1(1), 82-90. https://doi.org/10.18196/ftl.118

Nelson, S. (2000). Teaching Collaborative Writing and Peer Review Techniques to Engineering and Technology Undergraduates. In Proceedings-Frontiers in Education Conference, 30th Annual. Kansas, MO, USA. https://doi.org/10.1109/FIE.2000.896636

Ng, Q. R., Renandya, W. A., \& Chong, M. Y. C. (2019). Extensive reading: Theory, research and implementation. Teflin Journal, 30(2), 171-186. https://doi.org/10.15639/teflinjournal.v30i2/171-186

Sukirman. (2016). Using collaborative writing in teaching writing. LANGKAWI, 2(1), 3346. https://doi.org/http://dx.doi.org/10.31332/lkw.v2i1.443

Veramuthu, P., \& Shah, P. M. (2020). Effectiveness of Collaborative Writing among Secondary School Students in an ESL Classroom. Creative Education, 11(01), 5467. https://doi.org/10.4236/ce.2020.111004

Yastıbaş, G. Ç., \& Yastıbaş, A. E. (2015). The Effect of Peer Feedback on Writing Anxiety in Turkish EFL (English as a Foreign Language) Students. Procedia - Social and Behavioral Sciences, 199, 530-538. https://doi.org/10.1016/j.sbspro.2015.07.543 